\title{
The 4.2 ka BP event: multi-proxy records from a closed lake in the northern margin of the East Asian summer monsoon
}

\author{
Jule Xiao $^{1,2,3}$, Shengrui Zhang ${ }^{1}$, Jiawei Fan ${ }^{1}$, Ruilin Wen ${ }^{1,2}$, Dayou Zhai ${ }^{4}$, Zhiping Tian $^{5}$, and Dabang Jiang ${ }^{5}$ \\ ${ }^{1}$ CAS Key Laboratory of Cenozoic Geology and Environment, Institute of Geology and Geophysics, \\ Chinese Academy of Sciences, Beijing 100029, China \\ ${ }^{2}$ CAS Center for Excellence in Life and Paleoenvironment, Beijing 100044, China \\ ${ }^{3}$ College of Earth and Planetary Sciences, University of Chinese Academy of Sciences, Beijing 100049, China \\ ${ }^{4}$ Yunnan Key Laboratory for Palaeobiology, Yunnan University, Kunming 650091, China \\ ${ }^{5}$ Nansen-Zhu International Research Centre, Institute of Atmospheric Physics, Chinese Academy of Sciences, \\ Beijing 100029, China
}

Correspondence: Jule Xiao (jlxiao@mail.iggcas.ac.cn)

Received: 10 June 2018 - Discussion started: 18 June 2018

Revised: 7 September 2018 - Accepted: 18 September 2018 - Published: 11 October 2018

\begin{abstract}
The $4.2 \mathrm{ka} \mathrm{BP}$ event has been widely investigated since it was suggested to be a possible cause for the collapse of ancient civilizations. With the growth of proxy records for decades, however, both its nature and its spatial pattern have become controversial. Here we examined multi-proxy data of the grain-size distribution, ostracode assemblage, pollen assemblage, and the pollen-reconstructed mean annual precipitation from a sediment core at Hulun Lake in northeastern Inner Mongolia spanning the period between 5000 and 3000 cal. yr BP to identify the nature and the associated mechanism of the $4.2 \mathrm{ka} \mathrm{BP}$ event occurring in the monsoonal region of eastern Asia. Higher sand fraction contents, littoral ostracode abundances, and Chenopodiaceae pollen percentages together with lower mean annual precipitation reveal a significant dry event at the interval of 42103840 cal. yr BP that could be a regional manifestation of the $4.2 \mathrm{ka} \mathrm{BP}$ event in the northern margin of the East Asian summer monsoon (EASM). We suggest that the drought would be caused by a decline in the intensity of the EASM on millennial-to-centennial scales that could be physically related to persistent cooling of surface waters in the western tropical Pacific and the North Atlantic. The cooling of western tropical Pacific surface waters could reduce moisture production over the source area of the EASM, while the cooling of North Atlantic surface waters could suppress northward migrations of the EASM rain belt, both leading to a weak-
\end{abstract}

ened EASM and thus decreased rainfall in the northern margin of the EASM.

\section{Introduction}

In the early 1990s, Weiss et al. (1993) identified a marked increase in aridity and wind circulation occurring in northern Mesopotamia at $2200 \mathrm{BC}$ based on studies of archaeological sites on alluvial plains of the Tigris and Euphrates rivers, suggesting that the abrupt climatic change induced a considerable degradation of land-use conditions and thus caused the collapse of the rain-fed agriculture civilization of western Asia. Years later, two articles published in the periodical "Science" (Weiss and Bradley, 2001; deMenocal, 2001) demonstrated that the drought that occurred $4.2 \mathrm{ka}$ ago could be a possible cause for the collapse of ancient civilizations, which promoted extensive investigations into the abrupt climatic change occurring around $4.2 \mathrm{ka} \mathrm{BP}$ and the causal relationship between the cultural collapse and the $4.2 \mathrm{kaBP}$ event.

The Holocene climatic instability has actually become a hot topic of paleoclimate research since the 1990s. Unfortunately no clear signals of the $4.2 \mathrm{ka} \mathrm{BP}$ event were identified from the proxies of Greenland ice-core records, including oxygen isotope composition (Dansgaard et al., 1993), sea salt and terrestrial dust concentrations (O’Brien et al., 1995), 
and accumulation rate, temperature, and chloride, calcium, and methane concentrations (Alley et al., 1997). Although a series of abrupt shifts were detected for the Holocene climate of the North Atlantic through an investigation of ice-rafted debris in the deep-sea sediments, the $4.2 \mathrm{ka} \mathrm{BP}$ event appears unexceptional (Bond et al., 1997). These data imply that the $4.2 \mathrm{kaBP}$ event could be more complicated than previously recognized. Despite the attempts made over the years, in fact, the nature of the $4.2 \mathrm{ka} \mathrm{BP}$ event itself remains controversial (Marchant and Hooghiemstra, 2004; Magny et al., 2009), especially its impact on prehistoric cultures (Drysdale et al., 2006; Staubwasser and Weiss, 2006).

Research on the $4.2 \mathrm{kaBP}$ event and its impact on cultural evolution in China have been motivated by Hsü's view that famines and mass migrations occurring in ancient China could have resulted from regional droughts related to global cooling (Hsü, 1998). Wu and Liu (2004) synthesized data from paleoclimatic records in eastern China and suggested that the climatic anomaly that occurred $\sim 4.2 \mathrm{ka}$ ago produced a drought in the north and flooding in the south, which was responsible for the collapse of neolithic cultures in the central plain of China during the late third millennium BC. Liu and Feng (2012) recently examined the newly published data of paleoclimatic and archaeological records spanning the transition from the middle to late Holocene and offered a different interpretation from that of $\mathrm{Wu}$ and $\mathrm{Liu}$ (2004). In brief, an abrupt climatic shift occurred in northern China at $\sim 4$ cal. ka BP, while in southern China the $\sim 4 \mathrm{kaBP}$ event had several effects. With the associated climatic drying at $\sim 4$ cal. ka BP, Chinese neolithic cultures both in the north and in the south collapsed, while the Longshan culture in the central plain thrived.

Here we examine the paleoclimatic data from a sediment core at Hulun Lake in northeastern Inner Mongolia and focus on the $4.2 \mathrm{ka} \mathrm{BP}$ event occurring in the lake region. Hulun Lake is located in the northern margin of the East Asian summer monsoon that represents a climatically sensitive zone. The multi-proxy paleoclimatic records from the lake could provide new insights into the $4.2 \mathrm{kaBP}$ event. This study is aimed at identifying the nature and the associated mechanism of the $4.2 \mathrm{kaBP}$ event occurring in the monsoonal region of eastern Asia.

\section{Study site}

Hulun Lake $\left(48^{\circ} 30.667^{\prime}\right.$ to $49^{\circ} 20.667^{\prime} \mathrm{N}, 117^{\circ} 0.167^{\prime}$ to $\left.117^{\circ} 41.667^{\prime} \mathrm{E}\right)$, the fifth largest lake in China, is situated about $30 \mathrm{~km}$ south of Manchuria, Inner Mongolia, China (Fig. 1). It lies in an inland graben basin that was formed in the late Pliocene (Xu et al., 1989). It has an area of $2339 \mathrm{~km}^{2}$ and a maximum water depth of $8 \mathrm{~m}$ when the lake level is highest at an elevation of $545.3 \mathrm{~m}$ a.s.l. (measurements in August 1964; Xu et al., 1989). Today, the lake is closed and the maximum water depth is $5 \mathrm{~m}$ (Fig. 1). Low moun-

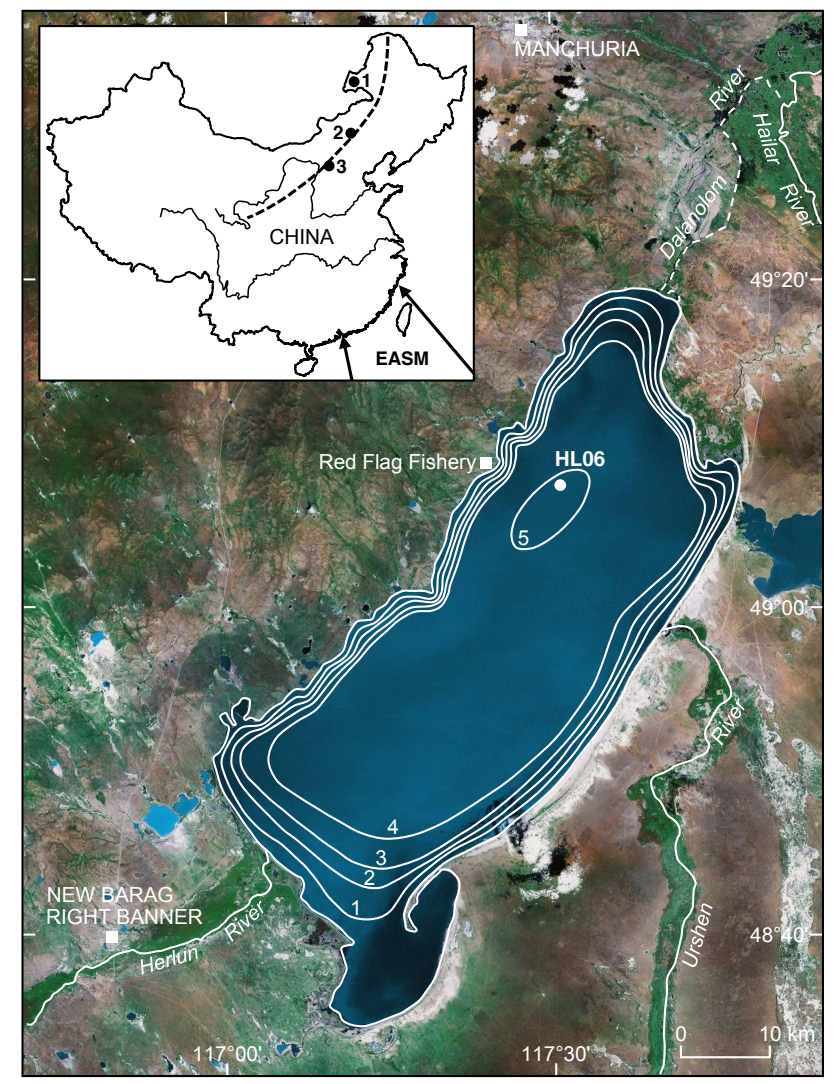

Figure 1. Map of Hulun Lake (from https://www.arcgis.com/home/ item.html?id=474c65ab3e1941468511785495eb8987, last access: 6 June 2018) showing the location of the HL06 core. A bathymetric survey of the lake was conducted in July 2005 with an FE606 Furuno echo sounder (contours in meters). The inset gives a sketch map of China showing the current northern limit of the East Asian summer monsoon (dashed line) defined as the $400 \mathrm{~mm}$ isohyet of mean annual precipitation (Chinese Academy of Sciences, 1984; Zhang and Lin, 1985) and the locations of the lakes (solid circles) mentioned in the present study. (1) Hulun Lake; (2) Dali Lake; (3) Daihai Lake. EASM in the inset indicates the East Asian summer monsoon.

tains and hills of Mesozoic volcanic rocks border the lake on the northwest and form a fault-scarp shoreline. Broad lacustrine and alluvial plains extend from the southern and eastern shores of the lake with scattered aeolian dunes. The lake has a catchment of $37214 \mathrm{~km}^{2}$ within the borders of China. Two rivers, the Herlun from the southwest and the Urshen from the southeast, supply water for the lake (Fig. 1). The Dalanolom River, an intermittent river to the northeast of the lake, drains the lake when the elevation of the lake level exceeds $543.4 \mathrm{~m}$ a.s.l. and enters the lake when the lake level is lower and the discharge of the Hailar River is larger as well (Xu et al., 1989) (Fig. 1).

Hulun Lake is located in a semi-arid area of the middle temperate zone (Fig. 1). The climate of the lake region is influenced by the East Asian monsoon and the westerlies 
(Chinese Academy of Sciences, 1984; Zhang and Lin, 1985). During summer, warm, moist southerly air masses interact with cold air from the northwest and produce most of the annual precipitation. During winter, cold, dry northwesterly airflows prevail and generate strong winds and cold weather. In the lake region, mean annual temperature is $0.3^{\circ} \mathrm{C}$ with a July average of $20.3{ }^{\circ} \mathrm{C}$ and a January average of $-21.2^{\circ} \mathrm{C}$. Annual precipitation is 247 to $319 \mathrm{~mm}$, and over $80 \%$ of the annual precipitation falls in June-September. Annual evaporation reaches 1400 to $1900 \mathrm{~mm}$. The lake is covered with $\sim 1 \mathrm{~m}$ of ice from November to April.

The ostracodes living in the lake today include Limnocythere inopinata (Baird), Candoniella suzini Schneider, Pseudocandona albicans (Brady), Pseudocandona compressa (Koch),Cyclocypris serena (Koch), Ilyocypris gibba (Ramdohr), and Ilyocypris salebrosa Stepanaiths (Xu et al., 1989; Wang and Ji, 1995). Limnocythere inopinata is the dominant species. Aquatic plants are scarce in the lake and confined to the areas of the river mouth and parts of the nearshore zone.

The modern natural vegetation of the lake basin belongs to the middle temperate steppe (Compilatory Commission of Vegetation of China, 1980; Xu et al., 1989). The vegetation cover ranges from relatively moist forb grass meadow steppe in the piedmont belt to moderately dry grass steppe on the alluvial plain and dry bunchgrass-undershrub Artemisia steppe on the lacustrine plain. Halophilic Chenopodiaceae plants are distributed in the lowlands. The forests are developed on the west slopes of the Great Hinggan Range, where the Urshen and Hailar River rise, accompanied by scrubs and herbs under the trees. Larch forests cover the southern part of the Hentiy Mountains where the Herlun River rises. Patches of pine forests and birch shrubberies occur in the alpine belt.

\section{Material and methods}

\subsection{Lithology and chronology of the HLO6 core}

Drilling was conducted at a water depth of $5 \mathrm{~m}$ in the central part of Hulun Lake in January 2006 when the lake was frozen (Fig. 1) using a TOHO drilling system. A sediment core was extracted to a depth beneath the lake floor of $1.7 \mathrm{~m}$ and is designated HL06 $\left(49^{\circ} 07.615^{\prime} \mathrm{N}, 117^{\circ} 30.356^{\prime}\right.$ E; Fig. 1). The core section was split, photographed, and described on-site; it was then cut into $1 \mathrm{~cm}$ segments, resulting in 170 samples for laboratory analyses.

The sediments of the HL06 core can be divided into three parts: (1) upper blackish grey oozy mud at depths of 0$35 \mathrm{~cm}$, (2) middle dark grey to blackish grey, massive sandy mud with scattered fragments of ostracodes and mollusk shells at depths of $35-100 \mathrm{~cm}$, and (3) lower greenish grey homogeneous mud at depths of $100-170 \mathrm{~cm}$ (Xiao et al., 2009).

A total of 13 bulk samples were collected from organicrich horizons of the HL06 core and dated with an accelerator mass spectrometry (AMS) system (compact AMS, NEC Pelletron) at Paleo Labo Co., Ltd. in Japan. As shown in Xiao et al. (2009), the uppermost $0-1 \mathrm{~cm}$ of the core sediments yields a ${ }^{14} \mathrm{C}$ age of $685 \pm 21$ years that was considered to result from carbon reservoir effects on radiocarbon dating of the bulk organic matter of Hulun Lake sediments. To produce an agedepth model for the HL06 core, the carbon reservoir age of $685 \pm 21$ years was first subtracted from all the original ${ }^{14} \mathrm{C}$ ages, and then calibrations were performed on the carbonreservoir-free ${ }^{14} \mathrm{C}$ ages. The conventional ages were converted to calibrated ages using the $\mathrm{OxCal3}$.1 radiocarbon age calibration program (Bronk Ramsey, 2001) with the IntCal04 calibration data (Reimer et al., 2004). The age-depth model indicates that the HL06 core covers the last $\sim 11000$ years (Xiao et al., 2009).

\subsection{Proxy analyses of the HL06 core}

The HL06 core has been analyzed at $1 \mathrm{~cm}$ intervals for multiple proxies, including grain-size distribution (Xiao et al., 2009), ostracode assemblage (Zhai et al., 2011), and pollen assemblage (Wen et al., 2010a), in order to investigate the Holocene history of changes in the hydrology of Hulun Lake and in the vegetation and climate of the lake region. Grainsize distribution was determined with a Malvern Mastersizer 2000 laser grain-size analyzer (Xiao et al., 2009). Each sample of sediment was pretreated with hydrogen peroxide to remove organic matter and then with boiled hydrochloric acid to remove carbonates. The sample residue was dispersed with sodium metaphosphate on an ultrasonic vibrator before grain-size analysis.

For the ostracode assemblage analysis, each sample of $\sim 300 \mathrm{mg}$ of air-dried sediment was pretreated with hydrogen peroxide-sodium carbonate solution ( $\mathrm{pH} 9-10)$ to disaggregate the sediment (Zhai et al., 2011). Fossil ostracode valves were extracted by sieving in water through a 250 mesh sieve ( $63 \mu \mathrm{m}$ pore size). Ostracode was identified and counted from the sieve residue spread onto a glass plate with an Olympus stereomicroscope at $40 \times$ magnification following the taxonomy of Meisch (2000) and Hou et al. (2002). Most samples yielded 300 to 4000 ostracode valves.

For the pollen assemblage analysis, each sample of $\sim 1 \mathrm{~g}$ of air-dried sediment was pretreated with hydrochloric acid to remove carbonates and with sodium hydroxide to remove organic matter; the residue was then kept in hydrofluoric acid to remove silicates (Wen et al., 2010a). Fossil pollen grains were extracted by wet sieving of the resulting residue through a sieve diameter of $10 \mu \mathrm{m}$ with an ultrasonic cleaner. Pollen was identified and counted with an Olympus light microscope at $400 \times$ magnification. More than 600 pollen grains were counted for each sample. The percentages of tree and herb pollen taxa were based on the sum of the total terrestrial pollen in a sample, and those of each taxon of both aquatic pollen and fern spores based on the sum of the terrestrial 


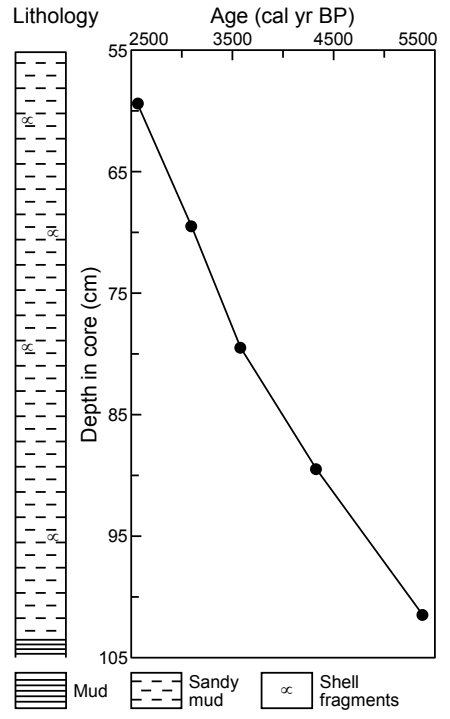

Figure 2. Lithological log and age-depth model of the segment of the HL06 core between 105 and $55 \mathrm{~cm}$ at core depth (covering the period between 5000 and 3000 cal. yr BP). Solid circles represent the mean values of $2 \sigma$ ranges of calibrated ages of carbon-reservoircorrected radiocarbon dates. The carbon reservoir correction factor is $685 \pm 21$ years, which is the ${ }^{14} \mathrm{C}$ age of the uppermost $1 \mathrm{~cm}$ of the core sediments. Modified after Xiao et al. (2009).

pollen plus the aquatic pollen or fern spores of the taxon in a sample.

In addition, the history of changes in precipitation in the Hulun Lake region during the Holocene was quantitatively reconstructed (Wen et al., 2010b) based on the pollen profile of the HL06 core (Wen et al., 2010a), using a pollenclimate transfer function for temperate eastern Asia (Wen et al., 2013).

\subsection{Proxy data from the HL06 core used for the present study}

The segment of the HL06 core spanning the period between 5000 and $3000 \mathrm{cal}$. yr BP is used for the present study to focus on the $4.2 \mathrm{kaBP}$ event occurring in the Hulun Lake region. Figure 2 shows the lithology and ages of the core segment between 105 and $55 \mathrm{~cm}$ at depth, which covers the segment between dated horizons of a calibrated age older than $5000 \mathrm{cal}$. yr BP and of a calibrated age younger than 3000 cal. yr BP. Ages of sampled horizons of the core segment spanning the period of 5000-3000 cal. yr BP were derived by linear interpolation between radiocarbon-dated horizons using the mean values of $2 \sigma$ ranges of calibrated ages.

Data of grain-size distribution (Xiao et al., 2009), ostracode assemblage (Zhai et al., 2011), pollen assemblage (Wen et al., 2010a), and mean annual precipitation (Wen et al., 2010b) from the HL06 core for the period of 5000$3000 \mathrm{cal}$. yr BP were reexamined in the present study in or- der to explore the detailed process of climate changes on millennial-to-centennial scales in the Hulun Lake region around $4.2 \mathrm{cal}$. ka BP.

\section{Results}

The sediments of the core segment spanning the period of 5000-3000 cal. yr BP consist of dark grey to blackish grey, massive sandy mud in which the scattered fragments of ostracode and mollusk shells can be seen (Fig. 2). Five radiocarbon dates provide age controls for the core segment spanning the period of $5000-3000 \mathrm{cal}$. yr BP (corresponding to the core depths of 97-68 cm) (Fig. 2; Table 1). Data of sand fraction content, littoral ostracode abundance, Chenopodiaceae pollen percentage, and mean annual precipitation from the core segment spanning the period of 5000-3000 cal. yr BP were plotted against age in Fig. 3. The average and 1 standard deviation (SD) values for all proxy data for the period between 5000 and 3000 cal. yr BP are expressed.

As shown in Fig. 3, the content of the sand fraction in the core sediments has an average of $7.5 \%$ and SD of $6.3 \%$ for the period of $5000-3000 \mathrm{cal}$. yr BP. At the interval of 4430-3860 cal. yr BP (core depth: $91-83 \mathrm{~cm}$ ), the sand fraction content shows values higher than $1 \mathrm{SD}$ with a maximum of $21.1 \%$ and an average of $15.5 \%$. The abundance of the littoral ostracodes including Pseudocandona albicans, Pseudocandona spp., Candoniella subellipsoidea, and Cypridopsis spp. from the core sediments has an average of 22 valves $\mathrm{g}^{-1}$ and SD of 22 valves $^{-1}$ for the period of $5000-3000 \mathrm{cal}$. yr BP. At the interval of 4200 3420 cal. yr BP (core depth: $88-76 \mathrm{~cm}$ ), the littoral ostracode abundance shows values higher than $1 \mathrm{SD}$ with a maximum of 70 valves $\mathrm{g}^{-1}$ and an average of 44 valves $\mathrm{g}^{-1}$. The percentage of Chenopodiaceae pollen from the core sediments has an average of $42.9 \%$ and SD of $10.7 \%$ for the period of 5000-3000 cal. yr BP. At the interval of 4300-3830 cal. yr BP (core depth: $89-83 \mathrm{~cm}$ ), the Chenopodiaceae pollen percentage shows values higher than $1 \mathrm{SD}$ with a maximum of $60.2 \%$ and an average of $56.5 \%$. The mean annual precipitation in the lake region reconstructed on the pollen profile of the sediment core has an average of $297.3 \mathrm{~mm}$ and SD of $20.3 \mathrm{~mm}$ for the period of 5000-3000 cal. yr BP. At the interval of 4240-3750 cal. yr BP (core depth: $88-82 \mathrm{~cm}$ ), the mean annual precipitation shows values lower than $1 \mathrm{SD}$ with a minimum of $264.0 \mathrm{~mm}$ and an average of $272.3 \mathrm{~mm}$.

\section{Discussion}

\subsection{Climatic implication of proxy data from the HL06 core}

Grain-size distributions of the core sediments show that the clay, silt, and sand fractions average $35.8 \%, 60.6 \%$, and $3.6 \%$ of the clastic materials during the Holocene, respectively (Xiao et al., 2009). Sand grains from the nearshore 


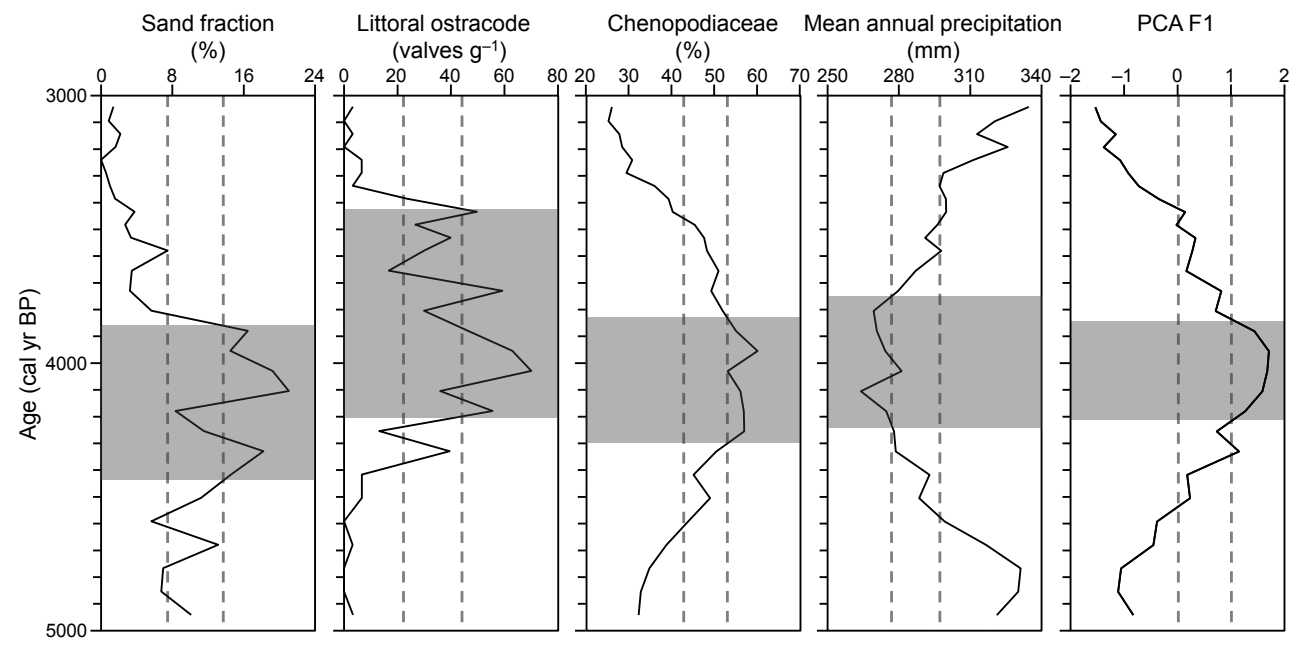

Figure 3. Time series of sand fraction (\%) (Xiao et al., 2009), littoral ostracode valves (valves $\mathrm{g}^{-1}$ ) (Zhai et al., 2011), Chenopodiaceae pollen (\%) (Wen et al., 2010a), and mean annual precipitation ( $\mathrm{mm}$ ) (Wen et al., 2010b) from the HL06 core spanning the period between 5000 and 3000 cal. yr BP as well as the PCA F1 obtained from the aforementioned four proxies. The chronology was derived from the carbonreservoir-corrected age-depth model; ages of sampled horizons were determined by linear interpolation between radiocarbon-dated horizons using the mean values of $2 \sigma$ ranges of calibrated ages (Xiao et al., 2009). Vertical dashed lines show the averages and 1 standard deviations above and below the averages of each proxy data as well as PCA F1 values during the period between 5000 and 3000 cal. yr BP. Light grey bars mark the intervals at which each proxy or PCA F1 has values higher than 1 standard deviation (lower than 1 standard deviation for mean annual precipitation).

Table 1. AMS radiocarbon dates of samples from the segment of the HL06 core between 105 and $55 \mathrm{~cm}$ at core depth (covering the period between 5000 and $3000 \mathrm{cal}$. yr BP). The radiocarbon date of the uppermost $1 \mathrm{~cm}$ of the core sediments used for carbon reservoir correction is shown. Modified after Xiao et al. (2009).

\begin{tabular}{lrlrrrr}
\hline $\begin{array}{l}\text { Laboratory } \\
\text { number }^{\mathrm{a}}\end{array}$ & $\begin{array}{r}\text { Depth interval } \\
(\mathrm{cm})\end{array}$ & $\begin{array}{l}\text { Dating } \\
\text { material }\end{array}$ & $\delta^{13} \mathrm{C}(\%)$ & $\begin{array}{r}\mathrm{AMS}{ }^{14} \mathrm{C} \text { age } \\
\left({ }^{14} \mathrm{C} \text { yr BP}\right)\end{array}$ & $\begin{array}{r}\text { Corrected }{ }^{14} \mathrm{C} \text { age }{ }^{\mathrm{b}} \\
\left({ }^{14} \mathrm{C} \text { yr BP}\right)\end{array}$ & $\begin{array}{r}\text { Calibrated }{ }^{14} \mathrm{C} \text { age } \\
(2 \sigma)(\text { cal yr BP })\end{array}$ \\
\hline PLD-7489 & $0-1$ & Organic matter & -26.94 & $685 \pm 21$ & $0 \pm 30$ & $0-10$ \\
PLD-7925 & $59-60$ & Organic matter & -26.57 & $3222 \pm 29$ & $2537 \pm 36$ & $2480-2650$ \\
PLD-7495 & $69-70$ & Organic matter & -27.73 & $3630 \pm 27$ & $2945 \pm 34$ & $2970-3220$ \\
PLD-7926 & $79-80$ & Organic matter & -26.72 & $4034 \pm 30$ & $3349 \pm 37$ & $3470-3690$ \\
PLD-7927 & $89-90$ & Organic matter & -25.40 & $4575 \pm 31$ & $3890 \pm 37$ & $4230-4430$ \\
PLD-7496 & $101-102$ & Organic matter & -28.38 & $5304 \pm 27$ & $4619 \pm 34$ & $5290-5470$ \\
\hline
\end{tabular}

${ }^{a}$ Laboratory code of Paleo Labo Co., Ltd., Japan. ${ }^{b}$ The reservoir correction factor is $685 \pm 21$ years, which is the ${ }^{14} \mathrm{C}$ age of the uppermost $1 \mathrm{~cm}$ of the core sediments.

zone of Hulun Lake could be transported to and deposited in the central part of the lake when the lake level was low. Therefore, increases in the relative percentage of the sand fraction in the core sediments were interpreted to indicate drops in the water level of Hulun Lake (Xiao et al., 2009). We thus infer that higher values of the sand fraction content at the interval of 4430-3860 cal. yr BP imply lower lake levels at that time (Fig. 3).

Ostracode assemblages of the core sediments suggest that 14 species of ostracodes belonging to nine genera occur in Hulun Lake during the Holocene and Limnocythere inopinata is the dominant species (Zhai et al., 2011). Pseudocandona albicans, Pseudocandona spp., Candoniella subellipsoidea, and Cypridopsis spp. from the core sediments were interpreted as littoral ostracode taxa because these ostracodes usually live in small water bodies and shallow waters and have a wide tolerance for water temperature and salinity (Zhai et al., 2011). We thus infer that higher values of the littoral ostracode abundance at the interval of 4200 3420 cal. yr BP imply lower lake levels at that time (Fig. 3).

Pollen assemblages of the core sediments suggest that dry grass steppe dominated by Artemisia and Chenopodiaceae plants were developed in the Hulun Lake basin during most of the Holocene (Wen et al., 2010a). In the modern steppe of northern China, Chenopodiaceae predominates over Artemisia in desert steppe compared with typical steppe. Therefore, increases in the relative percentage of Chenopodiaceae pollen in the core sediments were interpreted to in- 
dicate decreases in the effective moisture in the lake basin (Wen et al., 2010a). We thus infer that higher values of the Chenopodiaceae pollen percentage at the interval of 43003830 cal. yr BP imply lower effective moisture in the lake basin at that time (Fig. 3).

The pollen-reconstructed mean annual precipitation yields a value of around $285 \mathrm{~mm}$ in the Hulun Lake region for the last decades (Wen et al., 2010b). This value of the mean annual precipitation falls within the range of observed data of the annual precipitation (247-319 $\mathrm{mm}$ ), demonstrating the validity of the pollen-climate transfer function in quantitatively reconstructing the regional precipitation. Therefore, lower values of the mean annual precipitation at the interval of 4240-3750 cal. yr BP denote drier conditions in the lake basin at that time (Fig. 3).

\subsection{The nature and timing of the $4.2 \mathrm{kaBP}$ event in the Hulun Lake region}

As remarked above, the sand fraction content and the littoral ostracode abundance of the lake sediments can be used as indicators of changes in the lake level that are closely related to changes in the water balance (precipitation plus runoff minus evaporation) of the lake, while the Chenopodiaceae pollen percentage can be used as a direct indicator of changes in the effective moisture in the lake basin. The mean annual precipitation can directly indicate changes in the amount of precipitation in the lake basin. During the period of 50003000 cal. yr BP, data of the sand fraction content, littoral ostracode abundance, Chenopodiaceae pollen percentage, and the mean annual precipitation can be correlated with each other, although the intervals of a drier climate in the lake basin registered by different proxies differ in the time of start and end (Fig. 3). Discrepancies in the timing of the drier climate registered by different proxies might indicate differences in the response of different proxies to changes in the regional precipitation and the lake hydrology.

In order to detect the pattern of temporal changes in the regional dry-wet condition during the period of 50003000 cal. yr BP, principal component analysis (PCA) was performed to analyze the time series of data of the sand fraction content, littoral ostracode abundance, Chenopodiaceae pollen percentage, and the mean annual precipitation. All the raw data of the four proxies were standardized, and then PCA was conducted on the standardized data with the proxies as variables. F1, F2, and the first three factors of PCA capture $74.5 \%, 15.4 \%$, and $97.9 \%$ of the total variance within the data set, respectively. As shown in Fig. 3, PCA F1 has an average of 0 and SD of 1.02 for the period of 50003000 cal. yr BP. At the interval of 4210-3840 cal. yr BP (core depth: $88-83 \mathrm{~cm})$, PCA F1 displays values higher than $1 \mathrm{SD}$ with a maximum of 1.71 and an average of 1.54 (Fig. 3). PCA F1 reflects the most prominent common features of the aforementioned four proxies and defines a dry event in the
Hulun Lake region that started at 4210 cal. yr BP and ended at 3840 cal. yr BP, lasting for 370 years.

Studies on carbon concentrations of a sediment core at Dali Lake, south of Hulun Lake (see Fig. 1), reveal obvious decreases in total organic carbon concentration at 44503750 cal. yr BP, indicating a major interval of low lake stands and dry climatic conditions during the Holocene (Xiao et al., 2008). Moreover, a recent synthesis of grain-size distribution, carbon concentration, pollen assemblage, and pollenreconstructed precipitation from a sediment core at Daihai Lake, southwest of Hulun Lake (see Fig. 1), reflects a drought at 4060-3690 cal. yr BP (Xiao et al., 2018). These data lend support, within age uncertainties, to the inference of a dry event occurring in the Hulun Lake region in the present study. We thus suggest that the dry event that occurred in the $\mathrm{Hu}$ lun Lake region at 4210-3840 cal. yr BP could be the regional manifestation of the $4.2 \mathrm{ka} \mathrm{BP}$ event in the northern margin of the East Asian summer monsoon (EASM).

\subsection{Possible cause of the 4.2 ka BP event in the northern margin of the EASM}

Modern observations indicate that precipitation in the $\mathrm{Hu}$ lun Lake region reaches its peak value in July and $\sim 70 \%$ of the annual precipitation falls in late June through early August (Xu et al., 1989). Changes in the precipitation of the lake region in the summer half-year follow the northward migrations of the EASM rain belt (Fig. 4), indicating that increases in the precipitation of the northern margin of the EASM would be closely related to increases in the strength of the EASM. These data suggest that the dry event occurring in the northern margin of the EASM at 4210-3840 cal. yr BP implies a decline of the EASM at that interval.

The northward migrations of the EASM rain belt in the rainy seasons of East Asia are characterized by two discontinuous jumps (i.e., jumping first to the Yangtze RiverHuaihe River basin, southwestern Japan, and southern Korea in late June and then to northern China, northeastern China, and northern Korea in middle July after landing in southern China in late May) (Fig. 4), which are influenced not only by the ocean-atmosphere interactions in the tropical $\mathrm{Pa}$ cific because the moisture and rainfall brought by the EASM onto the land derives from the western tropical Pacific but also by the pattern of atmospheric circulation over Northern Hemisphere high latitudes because the EASM frontal rainfall results from the interaction between the warm-moist, southerly air masses and the cold to dry, northwesterly airflows (Chinese Academy of Sciences, 1984; Zhang and Lin, 1985). In Fig. 5, therefore, dry-wet oscillations in the Hulun Lake region reflected by PCA F1 for the period of 50003000 cal. yr BP are compared with the sea surface temperature (SST) record from the western tropical Pacific (Stott et al., 2004) and the hematite-stained grain (HSG) record from the North Atlantic (Bond et al., 2001). 

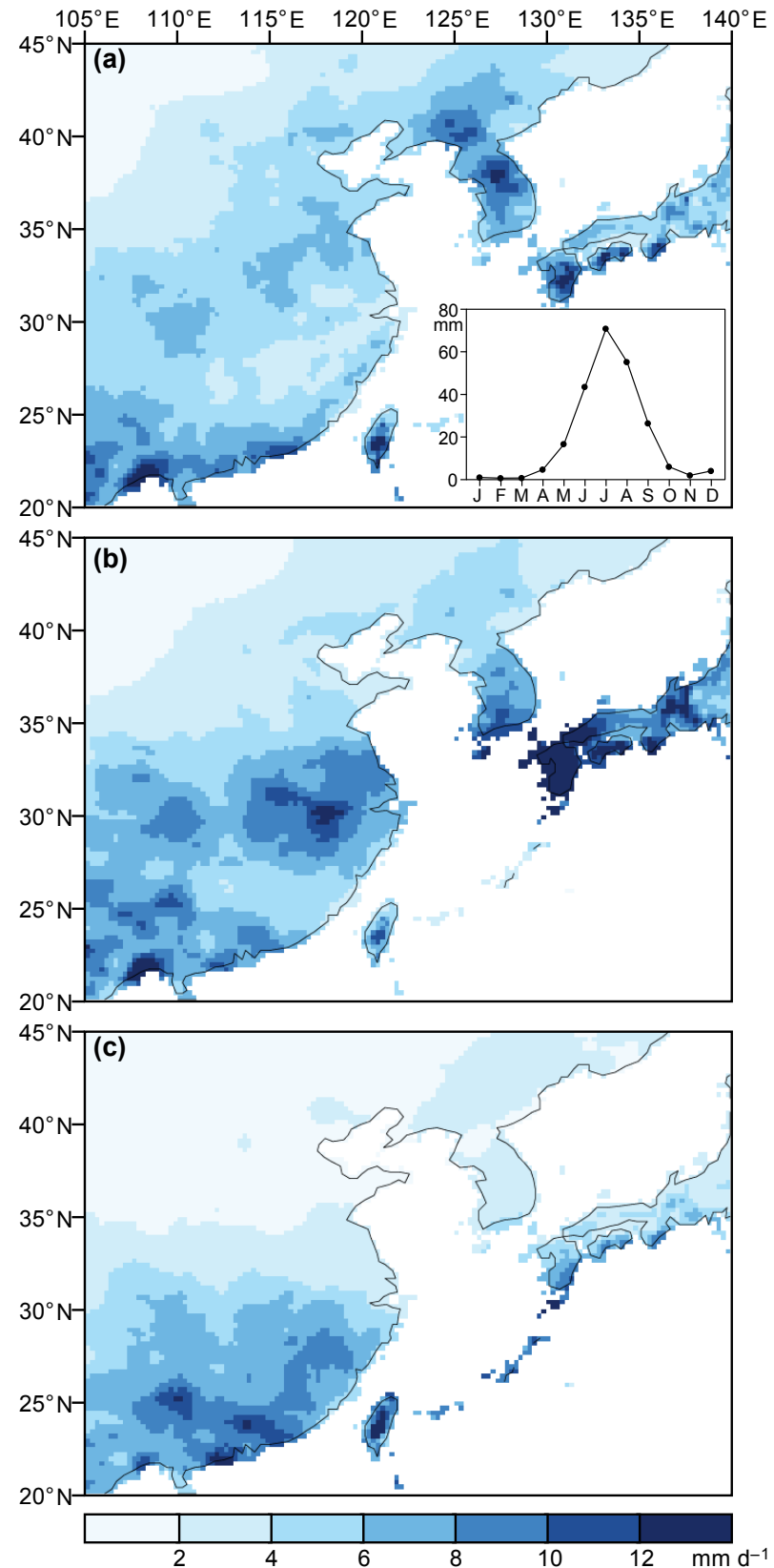

Figure 4. A sketch map of eastern China, Korea, and western Japan showing precipitation rates of the current East Asian summer monsoon. Data are averaged by observations of the years 1979-2007 and expressed in $\mathrm{mm} \mathrm{d}^{-1}$ at a grid resolution of $0.25^{\circ} \times 0.25^{\circ}$. (a) The 4th, 5th, and 6th pentads of July and the 1st pentad of August. (b) The 5th and 6th pentads of June and the 1st and 2nd pentads of July. (c) The 5th and 6th pentads of May and the 1st and 2nd pentads of June. The inset in Fig. 4a shows monthly changes in annual precipitation in the Hulun Lake region (data from observations of the years 1976-2005).

As shown in Fig. 5, the decline of the EASM occurring at $4210-3840$ cal. yr BP coincides, within age uncertainties, with decreases in the SST of the western tropical Pacific

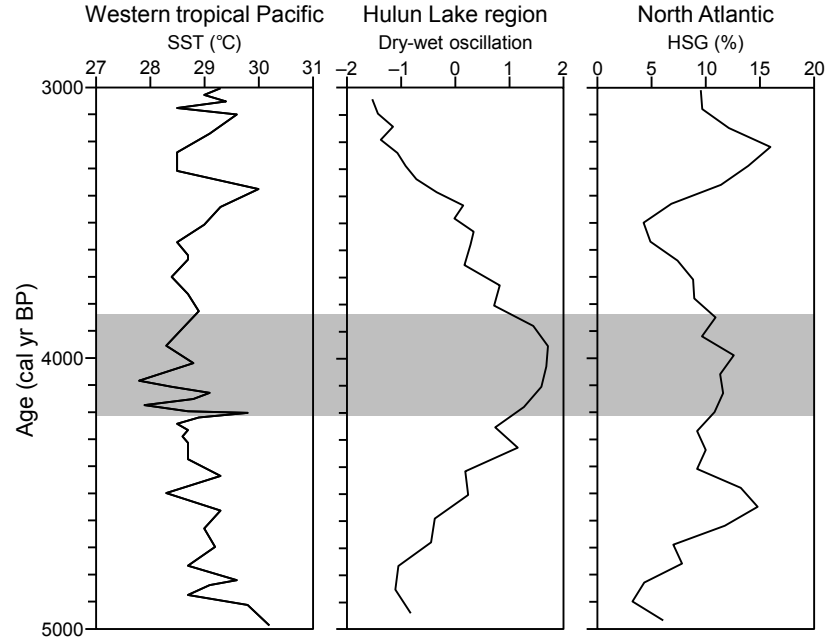

Figure 5. Correlation of dry-wet oscillation in the Hulun Lake region denoted by PCA F1 from the four proxies of the HL06 core with sea surface temperature $\left(\mathrm{SST},{ }^{\circ} \mathrm{C}\right)$ reconstructed on the $\mathrm{Mg}$ / Ca ratio of Globigerinoides rubber from the MD98-2176 core in the western tropical Pacific (Stott et al., 2004) and hematitestained grain concentration (HSG, \%) in the VM29-191 core from the North Atlantic (Bond et al., 2001). The shaded bar marks the interval of a dry event occurring in the Hulun Lake region at 4210 3840 cal. yr BP.

(Stott et al., 2004) and with increases in the HSG concentration in the North Atlantic sediments (Bond et al., 2001). This coincidence implies a physical link between the EASM decline on millennial-to-centennial scales and the persistent cooling of surface waters in the western tropical Pacific as well as the North Atlantic. In brief, continual decreases in sea surface temperature of the western tropical Pacific presumably caused by more intense, more frequent El Niño events (Moy et al., 2002) could reduce the formation of water vapor over the source area of the EASM, thereby decreasing the moisture available for transport via the EASM circulation from the western tropical Pacific onto the Asian inland and leading to a weakened EASM. Decreases in sea surface temperature of the North Atlantic could suppress the northward migration of the EASM front, thereby hampering the northward jumps of the EASM rain belt and resulting in weakened rainfall in the northern marginal zone of the EASM.

\section{Conclusions}

Multiple proxies of a sediment core at Hulun Lake in northeastern Inner Mongolia reveal a prominent dry event occurring in the lake region at the interval of 4210-3840 cal. yr BP that could be the regional manifestation of the $4.2 \mathrm{kaBP}$ event in the northern margin of the EASM. The drought would have resulted from a decline of the EASM that could be physically linked with the persistent cooling of surface 
waters in the western tropical Pacific and the North Atlantic on millennial-to-centennial scales.

Although more and more proxy data have been obtained, an integrated view of the $4.2 \mathrm{ka} \mathrm{BP}$ event is still far beyond reach. Future studies should be focused on the investigation of high-quality, high-resolution proxy records from more climatically sensitive and geographically representative regions in order to explore the spatiotemporal pattern of the $4.2 \mathrm{ka} \mathrm{BP}$ event and the associated dynamic mechanism.

Data availability. Research data from this study are available on request (jlxiao@mail.iggcas.ac.cn).

Author contributions. JX designed the research and wrote the paper; SZ, JF, RW and DZ performed research and analyzed data; ZT and DJ compiled Fig. 4; and all authors reviewed the paper.

Competing interests. The authors declare that they have no conflict of interest.

Special issue statement. This article is part of the special issue "The 4.2 ka BP climatic event". It is a result of "The $4.2 \mathrm{ka} \mathrm{BP}$ Event: An International Workshop", Pisa, Italy, 10-12 January 2018.

Acknowledgements. We thank Raymond Bradley, an anonymous referee, and Monica Bini for valuable comments that helped improve the original paper. This study was financially supported by the National Key R\&D Program of China (grant 2017YFA0603400) and the Strategic Priority Research Program of the Chinese Academy of Sciences (grant XDB26020203).

Edited by: Monica Bini

Reviewed by: Raymond Bradley and one anonymous referee

\section{References}

Alley, R. B., Mayewski, P. A., Sowers, T., Stuiver, M., Taylor, K. C., and Clark, P. U.: Holocene climatic instability: A prominent, widespread event 8200 yr ago, Geology, 25, 483-486, 1997.

Bond, G., Showers, W., Cheseby, M., Lotti, R., Almasi, P., deMenocal, P., Priore, P., Cullen, H., Hajdas, I., and Bonani, G.: A pervasive millennial-scale cycle in North Atlantic Holocene and glacial climates, Science, 278, 1257-1266, 1997.

Bond, G., Kromer, B., Beer, J., Muscheler, R., Evans, M. N., Showers, W., Hoffmann, S., Lotti-Bond, R., Hajdas, I., and Bonani, G.: Persistent solar influence on North Atlantic climate during the Holocene, Science, 294, 2130-2136, 2001.

Bronk Ramsey, C.: Development of the radiocarbon calibration program, Radiocarbon, 43, 355-363, 2001.
Chinese Academy of Sciences (Compilatory Commission of Physical Geography of China): Physical Geography of China: Climate, Science Press, Beijing, 1-30, 1984 (in Chinese).

Compilatory Commission of Vegetation of China: Vegetation of China, Science Press, Beijing, 932-955, 1980 (in Chinese).

Dansgaard, W., Johnsen, S. J., Clausen, H. B., Dahl-Jensen, D., Gundestrup, N. S., Hammer, C. U., Hvidberg, C. S., Steffensen, J. P., Sveinbjörnsdottir, A. E., Jouzel, J., and Bond, G.: Evidence for general instability of past climate from a 250-kyr ice-core record, Nature, 364, 218-220, 1993.

deMenocal, P. B.: Cultural responses to climate change during the late Holocene, Science, 292, 667-673, 2001.

Drysdale, R., Zanchetta, G., Hellstrom, J., Maas, R., Fallick, A., Pickett, M., Cartwright, I., and Piccini, L.: Late Holocene drought responsible for the collapse of Old World civilizations is recorded in an Italian cave flowstone, Geology, 34, 101-104, 2006.

Hou, Y. T., Gou, Y. X., and Chen, D. Q.: Fossil Ostracoda of China (Vol. 1), Science Press, Beijing, 1090 pp., 2002 (in Chinese).

Hsü, K. J.: Sun, climate, hunger, and mass migration, Sci. China Ser. D, 41, 449-472, 1998.

Liu, F. G. and Feng, Z. D.: A dramatic climatic transition at 4000 cal. yr BP and its cultural responses in Chinese cultural domains, Holocene, 22, 1181-1197, 2012.

Magny, M., Vannière, B., Zanchetta, G., Fouache, E., Touchais, G., Petrika, L., Coussot, C., Walter-Simonnet, A. V., and Arnaud, F.: Possible complexity of the climatic event around 4300$3800 \mathrm{cal}$. BP in the central and western Mediterranean, Holocene, 19, 823-833, 2009.

Marchant, R. and Hooghiemstra, H.: Rapid environmental change in African and South American tropics around 4000 years before present: a review, Earth-Sci. Rev., 66, 217-260, 2004.

Meisch, C.: Freshwater Ostracoda of Western and Central Europe, Spektrum, Heidelberg, 522 pp., 2000.

Moy, C. M., Seltzer, G. O., Rodbell, D. T., and Anderson, D. M.: Variability of El Niño/Southern Oscillation activity at millennial timescales during the Holocene epoch, Nature, 420, 162-165, 2002.

O’Brien, S. R., Mayewski, P. A., Meeker, L. D., Meese, D. A., Twickler, M. S., and Whitlow, S. I.: Complexity of Holocene climate as reconstructed from a Greenland ice core, Science, 270, 1962-1964, 1995.

Reimer, P. J., Baillie, M. G. L., Bard, E., Bayliss, A., Beck, J. W., Bertrand, C. J. H., Blackwell, P. G., Buck, C. E., Burr, G. S., Cutler, K. B., Damon, P. E., Edwards, R. L., Fairbanks, R. G., Friedrich, M., Guilderson, T. P., Hogg, A. G., Hughen, K. A., Kromer, B., McCormac, G., Manning, S., Bronk Ramsey, C., Reimer, R. W., Remmele, S., Southon, J. R., Stuiver, M., Talamo, S., Taylor, F. W., van der Plicht, J., and Weyhenmeyer, C. E.: Intcal04 terrestrial radiocarbon age calibration, 0-26 cal kyr BP, Radiocarbon, 46, 1029-1258, 2004.

Staubwasser, M. and Weiss, H.: Holocene climate and cultural evolution in late prehistoric-early historic West Asia, Quaternary Res., 66, 372-387, 2006.

Stott, L., Cannariato, K., Thunell, R., Haug, G. H., Koutavas, A., and Lund, S.: Decline of surface temperature and salinity in the western tropical Pacific Ocean in the Holocene epoch, Nature, 431, 56-59, 2004. 
Wang, S. M. and Ji, L.: Paleolimnology of Hulun Lake, University of Science and Technology of China Press, Hefei, 125 pp., 1995 (in Chinese).

Weiss, H. and Bradley, R. S.: What drives societal collapse?, Science, 291, 609-610, 2001.

Weiss, H., Courty, M. A., Wetterstrom, W., Guichard, F., Senior, L., Meadow, R., and Curnow, A.: The genesis and collapse of third millennium north Mesopotamian civilization, Science, 261, 9951004, 1993.

Wen, R. L., Xiao, J. L., Chang, Z. G., Zhai, D. Y., Xu, Q. H., Li, Y. C., Itoh, S., and Lomtatidze, Z.: Holocene climate changes in the mid-high latitude monsoon margin reflected by the pollen record from Hulun Lake, northeastern Inner Mongolia, Quaternary Res., 73, 293-303, 2010a.

Wen, R. L., Xiao, J. L., Chang, Z. G., Zhai, D. Y., Xu, Q. H., Li, Y. C., and Itoh, S.: Holocene precipitation and temperature variations in the East Asian monsoonal margin from pollen data from Hulun Lake in northeastern Inner Mongolia, China, Boreas, 39, 262-272, 2010b.

Wen, R. L., Xiao, J. L., Ma, Y. Z., Feng, Z. D., Li, Y. C., and Xu, Q. H.: Pollen-climate transfer functions intended for temperate eastern Asia, Quaternary Int., 311, 3-11, 2013.

Wu, W. X. and Liu, T. S.: Possible role of the "Holocene Event 3" on the collapse of Neolithic Cultures around the Central Plain of China, Quaternary Int., 117, 153-166, 2004.
Xiao, J. L., Si, B., Zhai, D. Y., Itoh, S., and Lomtatidze, Z.: Hydrology of Dali Lake in central-eastern Inner Mongolia and Holocene East Asian monsoon variability, J. Paleolimnol., 40, 519-528, 2008.

Xiao, J. L., Chang, Z. G., Wen, R. L., Zhai, D. Y., Itoh, S., and Lomtatidze, Z.: Holocene weak monsoon intervals indicated by low lake levels at Hulun Lake in the monsoonal margin region of northeastern Inner Mongolia, China, Holocene, 19, 899-908, 2009.

Xiao, J. L., Zhang, S. R., Fan, J.W.,Wen, R. L., Xu, Q. H., Inouchi, Y., and Nakamura, T.: The $4.2 \mathrm{ka}$ event and its resulting cultural interruption in the Daihai Lake basin at the East Asian summer monsoon margin, Quaternary Int., https://doi.org/10.1016/j.quaint.2018.06.025, 2018.

Xu, Z. J., Jiang, F. Y., Zhao, H. W., Zhang, Z. B., and Sun, L.: Annals of Hulun Lake, Jilin Literature and History Publishing House, Changchun, 691 pp., 1989 (in Chinese).

Zhai, D. Y., Xiao, J. L., Zhou, L., Wen, R. L., Chang, Z. G., Wang, X., Jin, X. D., Pang, Q. Q., and Itoh, S.: Holocene East Asian monsoon variation inferred from species assemblage and shell chemistry of the ostracodes from Hulun Lake, Inner Mongolia, Quaternary Res., 75, 512-522, 2011.

Zhang, J. C. and Lin, Z. G.: Climate of China, Shanghai Scientific and Technical Publishers, Shanghai, 603 pp., 1985 (in Chinese). 